\title{
Restudies of the spin state in (isothiocyanato)(pyridine)(porphinato)iron(III) hemipyridine complex. A spin-crossover complex with two magnetically distinct sites
}

\author{
Teng-Yuan Dong a,* ${ }^{\mathrm{a}}$, Pei-Har Ho ${ }^{\mathrm{a}}$, Ching-Hung Cheng ${ }^{\mathrm{a}}$, Yu Wang ${ }^{\mathrm{b}}$ \\ a Department of Chemistry, National Sun Yat-Sen University, Kaohsiung, Taiwan, ROC \\ ${ }^{\mathrm{b}}$ Department of Chemistry, National Taiwan University, Taipei, Taiwan, ROC
}

Received 28 October 1999; received in revised form 19 January 2000; accepted 25 January 2000

\begin{abstract}
The results of low-temperature X-ray determination, Mössbauer and magnetic measurement of spin-crossover (isothiocyanato)(pyridine)(porphinato)iron(III) hemipyridine are reported. The features in the $77 \mathrm{~K}$ Mössbauer spectrum include two doublets, one with a quadrupole splitting $\left(\Delta E_{\mathrm{Q}}\right)$ of $1.96 \mathrm{~mm} \mathrm{~s}^{-1}$ (low-spin site) and the other with $\Delta E_{\mathrm{Q}}=0.792 \mathrm{~mm} \mathrm{~s} \mathrm{~s}^{-1}$ (high-spin site). As the temperature of the sample is increased to $300 \mathrm{~K}$, the signal intensity of the high-spin site grows to $\sim 92 \%$ at the expense of the low-spin signal. The variable-temperature magnetic susceptibility data also support the fact that the tetraphenyl complex is a spin-crossover complex. (C) 2000 Elsevier Science S.A. All rights reserved.
\end{abstract}

Keywords: (Porphinato)iron(III); Spin-crossover; Porphyrin

\section{Introduction}

Characterization of the electronic structure of model heme complexes is very important in fully understanding the origin of electromagnetic properties, such as the changing in spin states that occurs during biological function of the heme proteins [1-7]. A heme enzyme of (thiocyanato)methemoglobin, (NCS)MetHb), has been shown to have unusual structural [8] and magnetic characterization [9]. It has been suggested that the anomalous magnetic property arises from a thermal spin equilibrium $(S=1 / 2, S=2 / 5)$; both human and horse derivatives are about $60 \%$ high spin at room temperature [9a]. Although the distribution of the highspin fraction between the $\alpha$ - and $\beta$-heme subunits is not known with certainty, the distribution most consistent

Abbreviations: MetHb, methemoglobin; Np, porphinato nitrogen atom; OEP, dianion of octaethylporphyrin; Py, pyridine; TPP, dianion of meso-tetraphenylporphyrin.

* Corresponding author. Fax: + 886-7-525 3908.

E-mail address: dty@mail.nsysu.edu.tw (T.-Y. Dong) with crystallographic results is about $20 \%$ on the $\alpha$ heme and $100 \%$ on the $\beta$-heme [9].

Binding of small molecules has been frequently exploited in studies of hemoproteins and porphyrin derivatives. These studies have focused particularly on exploring $\mathrm{O}_{2}, \mathrm{CO}, \mathrm{NO}, \mathrm{NCS}^{-}$, and $\mathrm{RCN}$ ( $\mathrm{R}=$ alkyl or aryl) ligation [7]. Drew et al. have determined the structure of the five-coordinate thiocyanato-ligated (porphinato)iron (III) complex, Fe(TPP)(NCS) (TPP, dianion of meso-tetraphenylporphyrin) [10]. This complex has an N-bonded linear $\mathrm{Fe}-\mathrm{NCS}$ group. In the case of (NCS)MetHb, the thiocyanate ligand is bound to the iron of heme through the nitrogen atom but with a distinctly nonlinear geometry $(\mathrm{Fe}-\mathrm{N}-\mathrm{C}$ angle $=$ $120 \pm 10^{\circ}$ ) [8]. Scheidt and co-workers have determined the structure of the six-coordinate (isothiocyanato)(pyridine)(meso-tetraphenylporphinato)iron (III), Fe(TPP)(NCS)(Py), to determine the effects of the presence of the sixth ligand on the mode of thiocyanate binding [11].

The variation of the magnetic moments from $5.1 \mu_{\mathrm{B}}$ at room temperature to $4.4 \mu_{\mathrm{B}}$ at $84 \mathrm{~K}$ for $\mathrm{Fe}(\mathrm{TPP})(\mathrm{NCS})(\mathrm{Py})$ suggests that this complex exhibits 
spin-crossover behavior typical of a number of iron(III) complexes [11a]. Scheidt et al. also reported the molecular stereochemistry of hemipyridine solvate (isothiocyanato)(pyridine)(meso-tetraphenylporphinato)iron-(III), $[\mathrm{Fe}(\mathrm{TPP})(\mathrm{NCS})(\mathrm{Py})] 1 / 2 \mathrm{Py} \quad[11 \mathrm{~b}]$. The structure of $[\mathrm{Fe}(\mathrm{TPP})(\mathrm{NCS})(\mathrm{Py})] 1 / 2 \mathrm{Py}$ is expected for a low-spin (porphinato)iron(III) species with an average $\mathrm{Fe}-\mathrm{Np}$ (porphinato nitrogen atom) distance of 1.988(9) А, $\mathrm{Fe}-\mathrm{N}(\mathrm{Py})=2.082(3) \AA$, and $\mathrm{Fe}-\mathrm{N}(\mathrm{NCS})=1.942(4) \AA$. The $\mathrm{Fe}-\mathrm{N}-\mathrm{C}-\mathrm{S}$ group is partly bent with an $\mathrm{Fe}-\mathrm{N}-\mathrm{C}$ angle of $155.6(3)^{\circ}$. The magnetic moment of $[\mathrm{Fe}(\mathrm{TPP})(\mathrm{NCS})(\mathrm{Py})] 1 / 2 \mathrm{Py}$ at $295 \mathrm{~K}$ is $3.67 \mu_{\mathrm{B}}$, decreasing to $3.04 \mu_{\mathrm{B}}$ at $77 \mathrm{~K}$ with a smaller temperature dependence. It is of interest that the magnetic moment of $[\mathrm{Fe}(\mathrm{TPP})(\mathrm{NCS})(\mathrm{Py})] 1 / 2 \mathrm{Py}$ at room temperature is higher than that of the typical low-spin state (2.15-2.7 $\mu_{\mathrm{B}}$ ).

We report herein the characterization of [Fe(TPP)(NCS)(Py)]1/2Py. This complex has been characterized by variable-temperature ${ }^{57} \mathrm{Fe}$ Mössbauer, magnetic measurement, EPR and low-temperature Xray determination.

\section{Experimental}

\subsection{Material}

The sample of $[\mathrm{Fe}(\mathrm{TPP})(\mathrm{NCS})(\mathrm{Py})] 1 / 2 \mathrm{Py}$, prepared by the procedure of Scheidt et al., was obtained in crystalline form [11b].

\subsection{Physical methods}

${ }^{57} \mathrm{Fe}$ Mössbauer measurements were made on a constant-velocity instrument that has been previously de-

Table 1

Experimental and crystal data

\begin{tabular}{ll}
\hline Formula & $\mathrm{C}_{52.5} \mathrm{H}_{35.5} \mathrm{FeN}_{6.5} \mathrm{~S}$ \\
Formula weight & 845.31 \\
Crystal system & Monoclinic \\
Space group & $P 2 . / n$ \\
$a(\AA)$ & $13.10(1)$ \\
$b(\AA)$ & $23.62(1)$ \\
$c(\AA)$ & $14.043(7)$ \\
$\beta\left({ }^{\circ}\right)$ & $104.80(7)$ \\
$\rho_{\text {calc }}\left(\mathrm{g} \mathrm{cm}^{-3}\right)$ & 1.334 \\
$V\left(\AA^{3}\right)$ & $4201(5)$ \\
$Z$ & 4 \\
$\mu\left(\mathrm{mm}^{-1}\right)$ & 0.45 \\
$\lambda(\AA)$ & 0.70930 \\
$2 \theta$ limits $\left(^{\circ}\right)$ & 49.9 \\
Max, min transmission coefficient & $0.999,0.744$ \\
$R_{\mathrm{f}}$ & 0.081 \\
$R_{\text {wf }}$ & 0.108 \\
\hline
\end{tabular}

scribed [12]. Computer fitting of the ${ }^{57} \mathrm{Fe}$ Mössbauer data to Lorentzian lines was carried out with a modified version of a previously reported program [13]. Velocity calibrations were made using a $99.99 \%$ pure 10 $\mu \mathrm{m}$ iron foil. Typical line widths for all three pairs of iron lines fell in the range $0.24-0.27 \mathrm{~mm} \mathrm{~s}^{-1}$. Isomer shifts are reported relative to the iron foil at $300 \mathrm{~K}$ but are uncorrected for temperature dependence. It should be noted that the isomer shifts illustrated in the Figures are plotted as experimentally obtained. Tabulated data are provided.

Variable-temperature $(4.2-300 \mathrm{~K})$ magnetic susceptibility data were measured with the use of a Quantum Design Squid MPMS susceptometer. The susceptometer was operated at a magnetic field strength $10 \mathrm{kG}$. Diamagnetic correction was estimated from Pascal's constants and applied to the calculated molar paramagnetic susceptibilities. The value of correction for $[\mathrm{Fe}(\mathrm{TPP})(\mathrm{NCS})(\mathrm{Py})] 1 / 2 \mathrm{Py} \quad$ is $\quad-4.947 \times 10^{-4} \mathrm{~cm}^{3}$ $\mathrm{mol}^{-1}$.

Electron paramagnetic resonance data (X-band) were collected with a Bruker ER200D-SRC spectrometer. The magnetic field was calibrated with a Bruker ER035N NMR gaussmeter. DPPH was used to gauge the microwave frequency. A direct-immersion dewar, which was inserted into the cavity, was use to obtain 77 $\mathrm{K}$ data.

\subsection{Structure determination of $[\mathrm{Fe}(\mathrm{TPP})(\mathrm{NCS})(\mathrm{Py})] 1 / 2 \mathrm{Py}$ at $110 \mathrm{~K}$}

A black crystal $\left(0.20 \times 0.75 \times 0.30 \mathrm{~mm}^{3}\right)$ was used for data collection at $110 \mathrm{~K}$. Cell dimensions (obtained from 25 reflections with $18.80^{\circ}<2 \theta<23.72^{\circ}$ ) and space group data were obtained by standard methods on an Enraf-Nonius CAD4 diffractometer. The $\theta-2 \theta$ scan technique was used to record the intensities for all reflections for which $1^{\circ}<2 \theta<49.9^{\circ}$. Absorption corrections were made with empirical $\varphi$ rotation. Of the 7396 unique reflections, there were 4475 with $F_{\mathrm{o}}>$ $2.0 \sigma\left(F_{\mathrm{o}}^{2}\right)$, where $\sigma\left(F_{\mathrm{o}}^{2}\right)$ values were estimated from counting statistics. These data were used in the final refinement of the structural parameters. The X-ray crystal data are summarized in Table 1.

A three-dimensional Patterson synthesis was used to determine the heavy-atom positions, which phased the data sufficiently well to permit location of the remaining non-hydrogen atoms from Fourier synthesis. All non-hydrogen atoms were refined anisotropically. During the final cycles of refinement, fixed hydrogen contributions with $\mathrm{C}-\mathrm{H}$ bond lengths fixed at $1.08 \AA$ were applied. The selected bond distances and angles are given in Table 2. Listings of the positional parameters, completed bond distances and angles, and thermal parameters are given as supplementary material (Section 5). 
Table 2

Selected bond distances $(\AA)$ and bond angles $\left(^{\circ}\right)$

\begin{tabular}{|c|c|c|c|c|c|}
\hline \multicolumn{6}{|l|}{ Bond distances } \\
\hline $\mathrm{Fe}-\mathrm{N}(1)$ & $1.98(7)$ & $\mathrm{Fe}-\mathrm{N}(2)$ & $1.974(7)$ & $\mathrm{Fe}-\mathrm{N}(3)$ & $1.970(7)$ \\
\hline $\mathrm{Fe}-\mathrm{N}(4)$ & $1.967(7)$ & $\mathrm{Fe}-\mathrm{N}(5)$ & $2.014(8)$ & $\mathrm{Fe}-\mathrm{N}(6)$ & $1.917(9)$ \\
\hline $\mathrm{S}-\mathrm{C}(30)$ & $1.65(1)$ & $\mathrm{N}(1)-\mathrm{C}(3 \mathrm{~A})$ & $1.39(1)$ & $\mathrm{N}(1)-\mathrm{C}(4 \mathrm{~A})$ & $1.38(1)$ \\
\hline $\mathrm{N}(3)-\mathrm{C}(8 \mathrm{~A})$ & $1.36(1)$ & $\mathrm{N}(4)-\mathrm{C}(5 \mathrm{~A})$ & $1.36(1)$ & $\mathrm{N}(4)-\mathrm{C}(6 \mathrm{~A})$ & $1.37(1)$ \\
\hline $\mathrm{N}(5)-\mathrm{C}(25)$ & $1.36(1)$ & $\mathrm{N}(5)-\mathrm{C}(29)$ & $1.36(1)$ & $\mathrm{N}(6)-\mathrm{C}(30)$ & $1.14(1)$ \\
\hline \multicolumn{6}{|l|}{ Bond angles } \\
\hline $\mathrm{N}(1)-\mathrm{Fe}-\mathrm{N}(4)$ & $89.9(3)$ & $\mathrm{N}(1)-\mathrm{Fe}-\mathrm{N}(5)$ & $88.1(3)$ & & \\
\hline $\mathrm{N}(1)-\mathrm{Fe}-\mathrm{N}(6)$ & $91.4(3)$ & $\mathrm{N}(2)-\mathrm{Fe}-\mathrm{N}(3)$ & $89.6(3)$ & & \\
\hline $\mathrm{N}(2)-\mathrm{Fe}-\mathrm{N}(4)$ & $179.4(3)$ & $\mathrm{N}(2)-\mathrm{Fe}-\mathrm{N}(5)$ & $90.9(3)$ & & \\
\hline $\mathrm{N}(2)-\mathrm{Fe}-\mathrm{N}(6)$ & $92.4(3)$ & $\mathrm{N}(3)-\mathrm{Fe}-\mathrm{N}(4)$ & $90.1(3)$ & & \\
\hline $\mathrm{N}(3)-\mathrm{Fe}-\mathrm{N}(5)$ & $90.3(3)$ & $\mathrm{N}(3)-\mathrm{Fe}-\mathrm{N}(6)$ & $90.3(3)$ & & \\
\hline $\mathrm{N}(4)-\mathrm{Fe}-\mathrm{N}(5)$ & $88.7(3)$ & $\mathrm{N}(4)-\mathrm{Fe}-\mathrm{N}(6)$ & $88.1(3)$ & & \\
\hline
\end{tabular}

\section{Results and discussion}

\subsection{Molecular structure}

The results of our crystallographic study at $110 \mathrm{~K}$ show that $[\mathrm{Fe}(\mathrm{TPP})(\mathrm{NCS})(\mathrm{Py})] 1 / 2 \mathrm{Py}$ crystallizes in the monoclinic space group $P 2_{1} / n$. An ORTEP drawing of the molecule is shown in Fig. 1, and selected bond distances and angles are given in Table 2. A comparison of $[\mathrm{Fe}(\mathrm{TPP})(\mathrm{NCS})(\mathrm{Py})] 1 / 2 \mathrm{Py}$ with other related molecules was also made (Table 3 ).

The low-temperature X-ray structure determination is similar to the previous $300 \mathrm{~K} \mathrm{X}$-ray structure determination [11b]. The average $\mathrm{Fe}-\mathrm{Np}$ distance (1.973(7) $\AA$ ) is shorter than the 1.988(9) $\AA$ distance observed at $300 \mathrm{~K}$. The axial $\mathrm{Fe}-\mathrm{N}_{\mathrm{Py}}$ and $\mathrm{Fe}-\mathrm{N}_{\mathrm{NCS}}$ distances (2.014(8) and 1.917(9) $\AA$, respectively) are also shorter than the corresponding 2.082(3) and 1.942(4) $\AA$ values of the $300 \mathrm{~K} \mathrm{X}$-ray determination. The angle between the two axial nitrogen ligands is nearly linear with $176.7(3)^{\circ}\left(176.3(1)^{\circ}\right.$ at the $300 \mathrm{~K}$ determination). As noted at the $300 \mathrm{~K}$ determination, the $\mathrm{Fe}-\mathrm{N}_{\mathrm{NCS}}$ group is non linear; the observed $\mathrm{Fe}-\mathrm{N}-\mathrm{C}$ angle $\left(158.1(7)^{\circ}\right)$ is similar to the $155.6(3)^{\circ}$ value for the $300 \mathrm{~K}$ determination. The $\mathrm{N}-\mathrm{C}-\mathrm{S}$ group is effectively linear with an angle of $179.0(9)^{\circ}$. The pyridine ring orientation is also similar in both cases and the angle $(\phi)$ between the pyridine plane and the coordinate plane $\mathrm{N}_{5} \mathrm{FeN}_{1}$ is $39^{\circ}$.

As described in Section 1, we are particularly interested in the spin state of the iron. In general, the $\mathrm{Fe}-\mathrm{Np}$ and $\mathrm{Fe}-\mathrm{Npy}$ distances can be used in determining the spin state of iron(III) porphyrinate. Scheidt et al. reported [11b] that the coordination group bond distance of $[\mathrm{Fe}(\mathrm{TPP})(\mathrm{NCS})(\mathrm{Py})] 1 / 2 \mathrm{Py}$ at $300 \mathrm{~K}$ is consistent with a low-spin iron(III) porphyrinate species. At the $300 \mathrm{~K}$ determination, the average $\mathrm{Fe}-\mathrm{Np}$ distance of $1.988(9) \AA$ is essentially identical with the 1.990
$\AA$ average value observed in eight other low-spin iron(III) porphyrinates [7]. The axial $\mathrm{Fe}-\mathrm{Npy}$ distance $(2.082(3) \AA)$ observed in $[\mathrm{Fe}(\mathrm{TPP})(\mathrm{NCS})(\mathrm{Py})] 1 / 2 \mathrm{Py}$ is similar to the 2.089(6) $\AA$ in low-spin $\operatorname{Fe}(\mathrm{TPP})\left(\mathrm{N}_{3}\right)(\mathrm{Py})$ [14], the 2.075(3) $\AA$ value for $\mathrm{Fe}(\mathrm{TPP})(\mathrm{CN})(\mathrm{Py})$ [15], and the 2.031(2) $\AA$ value in the low-spin form of $\left[\mathrm{Fe}(\mathrm{OEP})(3-\mathrm{ClPy})_{2}\right] \mathrm{ClO}_{4}$ (OEP, dianion of octaethylporphyrin) [16]. All of these distances are considerably smaller than the 2.316(5) $\AA$ value for $\mathrm{Fe}-\mathrm{N}(\mathrm{py})$ in the

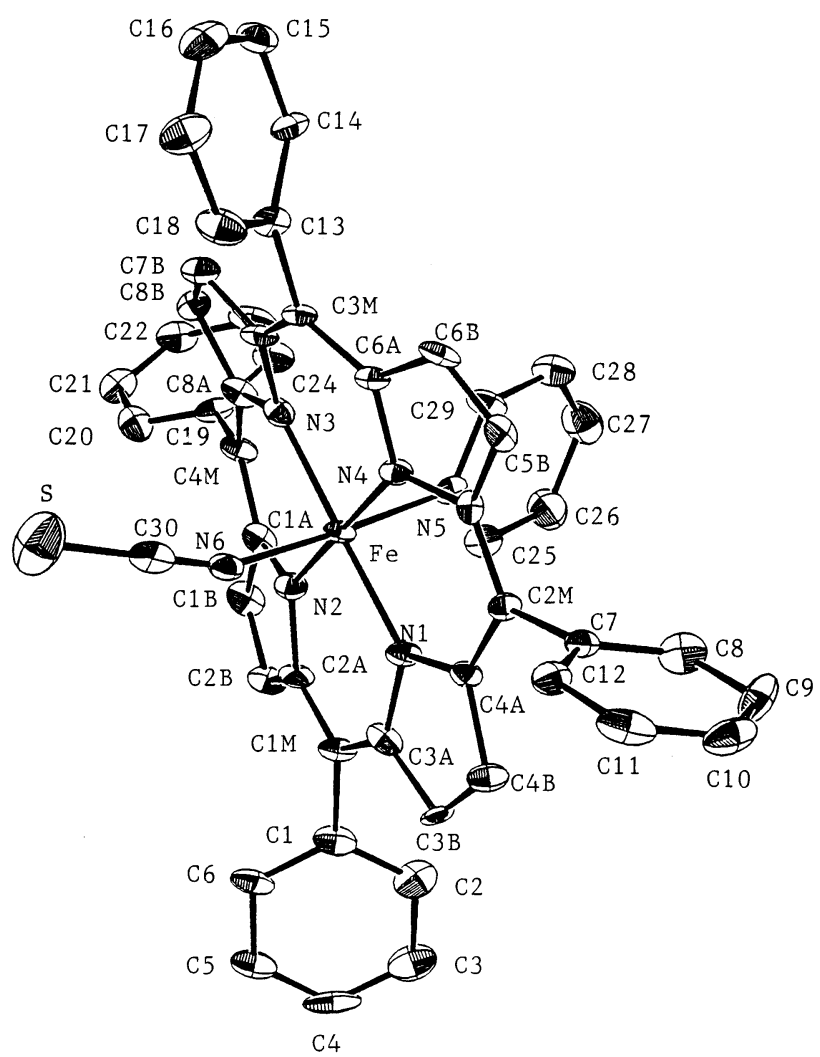

Fig. 1. ORTEP plot of $[\mathrm{Fe}(\mathrm{TPP})(\mathrm{Py})(\mathrm{NCS})] / / 2 \mathrm{Py}$ at $110 \mathrm{~K}$. 
Table 3

Comparison of the atomic distances and angles

\begin{tabular}{|c|c|c|c|c|c|c|}
\hline Compound & $T(\mathrm{~K})$ & Spin state ${ }^{f}$ & $\mathrm{Fe}-\mathrm{N}_{\mathrm{p}}$ & $\mathrm{Fe}-\mathrm{N}_{\mathrm{Py}}$ & $\mathrm{Fe}-\mathrm{N}_{\mathrm{NCS}}$ & $\mathrm{Fe}-\mathrm{N}-\mathrm{C}$ \\
\hline$[\mathrm{Fe}(\mathrm{TPP})(\mathrm{NCS})(\mathrm{Py})] 1 / 2 \mathrm{Py}{ }^{\mathrm{a}}$ & 300 & & $1.988(9)$ & $2.082(3)$ & $1.942(4)$ & $155.6(3)$ \\
\hline$[\mathrm{Fe}(\mathrm{TPP})(\mathrm{NCS})(\mathrm{Py})] 1 / 2 \mathrm{Py}{ }^{\mathrm{b}}$ & 100 & & $1.973(7)$ & $2.014(8)$ & $1.917(9)$ & $158.1(7)$ \\
\hline $\mathrm{Fe}(\mathrm{TPP})(\mathrm{CN})(\mathrm{Py})^{\mathrm{d}}$ & & LS & $1.970(3)$ & $2.075(3)$ & & \\
\hline \multirow{2}{*}[\mathrm{Fe}(\mathrm{OEP})(3-\mathrm{ClPy})_{2}]{$\mathrm{ClO}_{4}{ }^{\mathrm{e}}$} & 98 & LS & $1.994(2)$ & $2.031(2)$ & & \\
\hline & 293 & HS & & $2.316(5)$ & & \\
\hline
\end{tabular}

${ }^{\mathrm{a}}$ From Ref. [11b].

${ }^{\mathrm{b}}$ Our work at $110 \mathrm{~K}$.

${ }^{\mathrm{c}}$ From Ref. [14].

${ }^{\mathrm{d}}$ From Ref. [15].

e From Ref. [16].

${ }^{\mathrm{f}} \mathrm{HS}$, high-spin; LS, low-spin.

high-spin form of $\left[\mathrm{Fe}(\mathrm{OEP})(3-\mathrm{ClPy})_{2}\right] \mathrm{ClO}_{4}$. In our 110 $\mathrm{K}$ determination, we find a decrease of the $\mathrm{Fe}-\mathrm{Np}$ (0.015 $\AA$ shorter) and $\mathrm{Fe}-\mathrm{Npy}(0.068 \AA$ shorter $)$ distances.

Our interest is aroused by the commonness in determining the spin state of the heme group by single-crystal X-ray determination. Hence, we apply the Mössbauer technique, magnetic measurement, and EPR to further confirm the spin state. These measurements are against the existence of a single low-spin $[\mathrm{Fe}(\mathrm{TPP})(\mathrm{NCS})(\mathrm{Py})] 1 / 2 \mathrm{Py}$.

\section{2. ${ }^{57} \mathrm{Fe}$ Mössbauer characteristics}

Because of their biological importance, iron porphyrin complexes have been studied extensively by ${ }^{57} \mathrm{Fe}$ Mössbauer spectroscopy. The Mössbauer spectra of hemin, hemin salts, hematin, hemeglobin and its derivatives, cytochrome, and catalase have been reported in the literature [17]. The Mössbauer spectra of $[\mathrm{Fe}(\mathrm{TPP})(\mathrm{NCS})(\mathrm{Py})] 1 / 2 \mathrm{Py}$ at 300 and $77 \mathrm{~K}$ are shown in Fig. 2. The bold dots are experimental data and the smooth line represents the best computer fit with Lorentzian lines. The resulting fitting parameters are shown in Table 4.

${ }^{57} \mathrm{Fe}$ Mössbauer spectra offer convincing evidence for the presence of thermally induced spin-crossover. In every known case of thermal equilibrium between two spin states for either iron(II) or iron(III) complexes, Mössbauer spectra in the transition region show either gross line broadening or two doublets (depending on the spin relaxation times). The spectra of $[\mathrm{Fe}(\mathrm{TPP})(\mathrm{NCS})(\mathrm{Py})] 1 / 2 \mathrm{Py}$ were characterized by two broad asymmetric doublets at 298 and $77 \mathrm{~K}$. The features in the $77 \mathrm{~K}$ spectrum include two doublets, one with a quadrupole splitting $\left(\Delta E_{\mathrm{Q}}\right)$ of $1.96 \mathrm{~mm} \mathrm{~s}^{-1}$ (low-spin site) and the other with $\Delta E_{\mathrm{Q}}=0.79 \mathrm{~mm} \mathrm{~s}^{-1}$ (high-spin site). The observed $\Delta E_{\mathrm{Q}}$ values are consistent with those found for $S=1 / 2$ iron(III) porphyrins $\left(\sim 1.6-2.3 \mathrm{~mm} \mathrm{~s}^{-1}\right)$ and $S=5 / 2$ complexes $(\sim 0.6-1.3$ $\mathrm{mm} \mathrm{s}^{-1}$ ). As the temperature of the sample is increased to $300 \mathrm{~K}$, the signal intensity of the high-spin site grows to $92 \%$ at the expense of the low-spin signal. Thus, the pattern of two doublets and the changing of the relative intensity at different temperatures are expected for a spin-crossover complex.

In the spectra taken at 300 and $77 \mathrm{~K}$, the less-intense broadened peak lies on the higher-energy side and corresponds to the $\pm 1 / 2 \rightarrow \pm 3 / 2$ nuclear transition if the magnetic axis is parallel to the crystal field axis. An explanation of the asymmetry and temperature dependence of the Mössbauer spectra of hemin has been given by Blume [18].

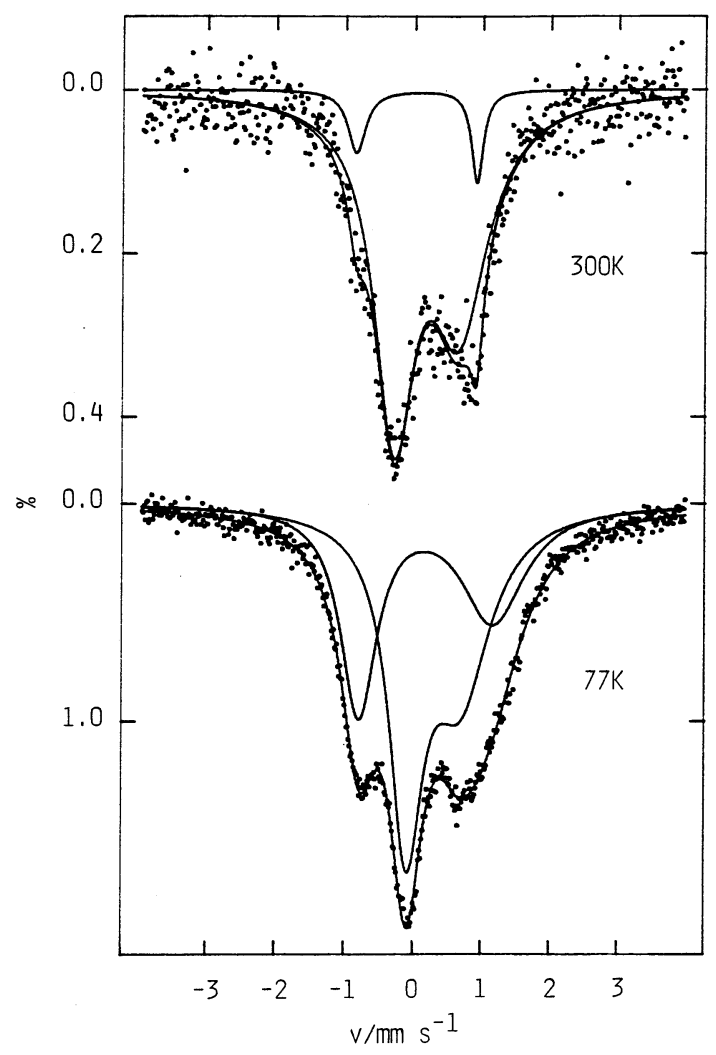

Fig. 2. ${ }^{57} \mathrm{Fe}$ Mössbauer spectra at 300 (top) and $77 \mathrm{~K}$ (bottom). 
Table 4

${ }^{57} \mathrm{Fe}$ Mössbauer data of $[\mathrm{Fe}(\mathrm{TPP})(\mathrm{NCS})(\mathrm{Py})] 1 / 2 \mathrm{Py}$

\begin{tabular}{llllrl}
\hline$T(\mathrm{~K})$ & $\mathrm{IS}^{\mathrm{a}}$ & $\Delta E_{\mathrm{Q}}{ }^{\mathrm{b}}$ & $\Gamma^{\mathrm{c}}$ & $\%^{\mathrm{d}}$ & Spin state $^{\mathrm{e}}$ \\
\hline 300 & 0.17 & 0.95 & $1.02,0.71$ & 91.9 & HS \\
& 0.03 & 1.76 & $0.21,0.32$ & 8.1 & $\mathrm{LS}$ \\
77 & 0.29 & 0.79 & $1.06,0.60$ & 59.0 & HS \\
& 0.18 & 1.96 & $1.13,0.64$ & 41.0 & LS \\
\hline
\end{tabular}

a Isomer shift referenced to iron foil in $\mathrm{mm} \mathrm{s}^{-1}$.

${ }^{\mathrm{b}}$ Quadrupole splitting in $\mathrm{mm} \mathrm{s}^{-1}$.

${ }^{\mathrm{c}}$ Full width at half-height taken from the least-squares fitting program. The width for the line at more positive velocity is listed first for each doublet.

d Area ratio.

${ }^{\mathrm{e}} \mathrm{HS}$, high-spin; LS, low-spin.

Table 5

EPR data

\begin{tabular}{lrl}
\hline Compound & $T(\mathrm{~K})$ & $g$ \\
\hline Fe(TPP)(NCS) & 300 & $5.20,2.00$ \\
& 77 & $5.20,2.00$ \\
{$[\mathrm{Fe}(\mathrm{TPP})(\mathrm{NCS})(\mathrm{Py})] 1 / 2 \mathrm{Py}$} & 300 & $5.15,2.30,2.00$ \\
& 77 & $5.45,2.62,2.35,2.00,1.48$ \\
\hline
\end{tabular}

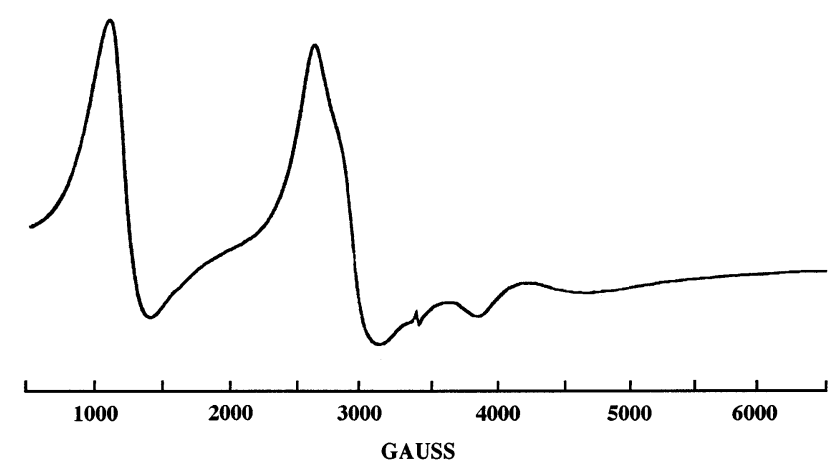

Fig. 3. EPR spectrum of $[\mathrm{Fe}(\mathrm{TPP})(\mathrm{Py})(\mathrm{NCS})] 1 / 2 \mathrm{Py}$ at $77 \mathrm{~K}$.

\subsection{Electron paramagnetic resonance}

As shown in Table 5, EPR has been used to estimate the spin state of $\mathrm{Fe}(\mathrm{III})$ porphyrin. A simple theory for the $S=5 / 2$ ground state would predict $g_{\perp}=6$ and $g_{/ /}=2$. Thus, the $\left[\mathrm{Fe}(\mathrm{TPP})(\mathrm{DMSO})_{2}\right] \mathrm{ClO}_{4}$ has an axial EPR spectrum found to be typical of high-spin ferric heme $\left(g_{\perp}=6.09\right.$ and $\left.g_{/ /}=2.00\right)$ [19]. On the other hand, the $\left[\mathrm{Fe}(\mathrm{TPP})(\mathrm{Im})_{2]} \mathrm{Cl}\right.$ has a rhombic EPR spectrum with a much reduced $g$-tensor anisotropy $\left(g_{1}=2.873, g_{2}=\right.$ 2.292, and $g_{3}=1.565$ ) [20].

Further evidence for the presence of thermally induced spin-crossover in $[\mathrm{Fe}(\mathrm{TPP})(\mathrm{NCS})(\mathrm{Py})] 1 / 2 \mathrm{Py}$, comes from the $77 \mathrm{~K}$ EPR spectrum, which is remarkably well shaped (Fig. 3). It is a typical spin-crossover EPR spectrum with $g$ values of 5.45, 2.62, 2.35, 2.00, and 1.48. The $g$ values at 5.45 and 2.00 are attributed to high-spin Fe(III) heme. Furthermore, the $g$ values at 2.62, 2.35 and 1.48 are attributed to low-spin Fe(III) heme.

\subsection{Magnetic measurements}

The variable-temperature magnetic susceptibilities also support the fact that the tetraphenyl complex is a spin-crossover complex. As shown in Fig. 4, the magnetic moment at room temperature is about $4.54 \mu_{\mathrm{B}}$ and decreases to about $3.96 \mu_{\mathrm{B}}$ at $100 \mathrm{~K}$. It is quite interesting to find that the magnetic moment remains constant between 100 and $8 \mathrm{~K}$. In the case of [Fe(TPP)(NCS)(Py)], which differs from the presently reported hemipyridine solvate in having no solvate molecule, Scheidt and co-worrkers also reported the observation of constant magnetic moment between 84 and $25 \mathrm{~K}$ [11a]. It is reasonable to interpret this phenomenon in terms of two magnetic sites: a high-spin site and a spin-crossover site. The spin state of the high-spin site ( $34 \%$ ) is taken to be $S=5 / 2$ between 300 and $8 \mathrm{~K}$, calculated from the magnetic data at $100 \mathrm{~K}^{1}$. The spin-crossover site (low spin at $100 \mathrm{~K}$ ) must be about $17 \%$ in the high-spin state and $49 \%$ in the low-spin state at $300 \mathrm{~K}$. As the temperature is decreased to $100 \mathrm{~K}$, the spin-crossover site should be in a low-spin state $(66 \%)$. However, it is noticeable that the ratio between the high-spin state and the low-spin state calculated from magnetic data is different from the area ratio of the high-spin state to the low-spin state in ${ }^{57} \mathrm{Fe}$ Mössbauer measurements. Here, we suggest that the difference in the ratio of the high-spin state to the low-spin state is a result of the difference in the recoilless fraction of the high-spin and low-spin states. In ${ }^{57} \mathrm{Fe}$ Mössbauer measurements, the recoilless fraction of the high-spin state is not necessarily equal to the recoilless fraction of the low-spin state.

This two-site interpretation has been proposed for the magnetic characterization of (thiocyanato)methemoglobin [8]. The hemes exit in a thermal spin equilibrium; both human and horse derivatives are about $60 \%$ high-spin at room temperature Although the distribution of the high-spin fraction between $\alpha$ and $\beta$ subunits is not known with certainty, the distribution must be consistent with crystallographic results of about $20 \%$ on the $\alpha$-heme and $100 \%$ on the $\beta$-heme.

\section{Conclusions}

Scheidt et al. reported that the coordination group bond distances of $[\mathrm{Fe}(\mathrm{TPP})(\mathrm{NCS})(\mathrm{Py})] 1 / 2 \mathrm{Py}$ at $300 \mathrm{~K}$ were consistent with a low-spin iron(III) porphyrinate

\footnotetext{
${ }^{1}$ The fraction, $\alpha$, in the high-spin state is calculated by $\mu^{2}=$ $\alpha\left(\mu_{\mathrm{hs}}\right)^{2}+(1-\alpha)\left(\mu_{\mathrm{ls}}\right)^{2}$, where $\mu_{\mathrm{hs}}=5.9$ and $\mu_{\mathrm{ls}}$ was taken to be $2.4 \mu_{\mathrm{B}}$.
} 


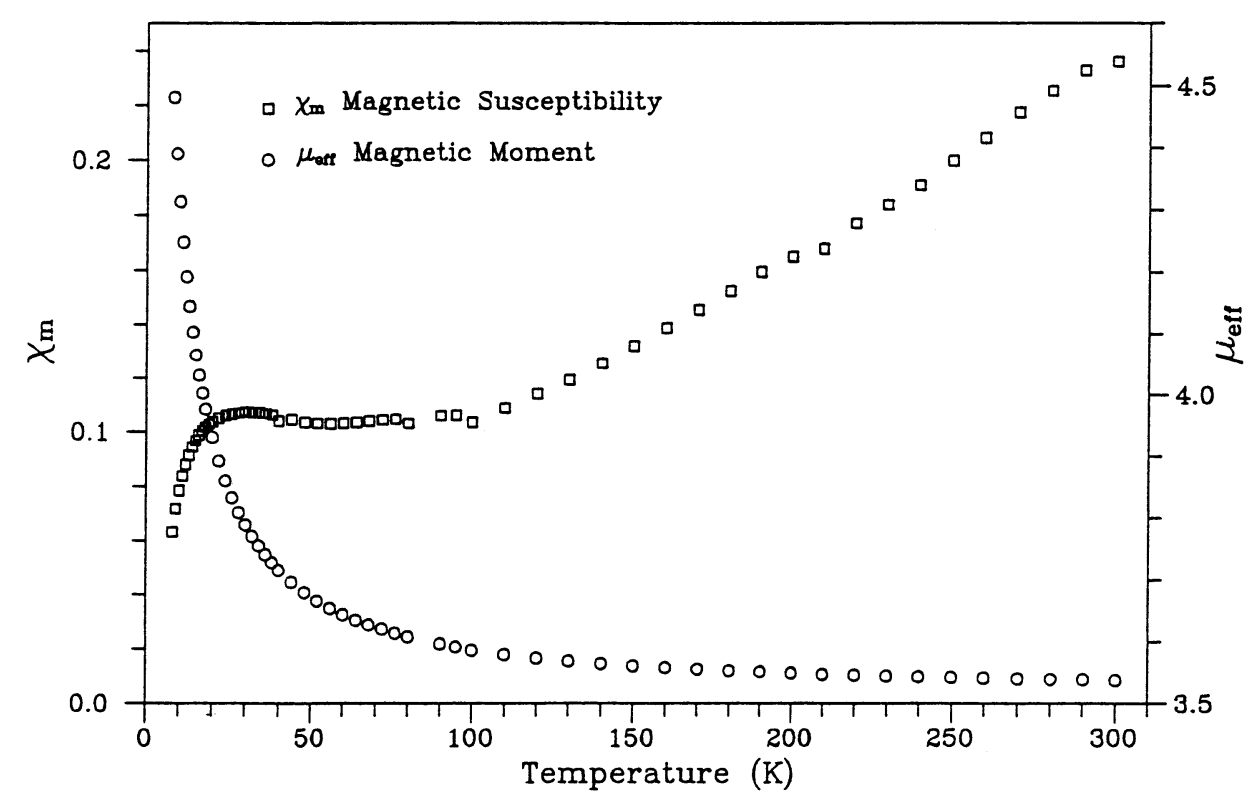

Fig. 4. Variable-temperature (300-4.2 K) magnetic susceptibility and magnetic moment.

species [11b]. However, the ${ }^{57} \mathrm{Fe}$ Mössbauer studies and EPR measurements indicate the presence of thermally induced spin-crossover. The temperature-dependent (300-4.2 K) magnetic moments suggest that the best explanation of the magnetism is given by a two-site model. One site of the $[\mathrm{Fe}(\mathrm{TPP})(\mathrm{NCS})(\mathrm{Py})] 1 / 2 \mathrm{Py}$ molecule is a high-spin site between 300 and $8 \mathrm{~K}$; the second site undergoes a low-spin-high-spin thermal equilibrium.

\section{Supplementary material}

Complete tables of positional parameters, bond lengths and angles, and thermal parameters of $[\mathrm{Fe}(\mathrm{TPP})(\mathrm{NCS})(\mathrm{Py})] 1 / 2 \mathrm{Py}$ (10 pages) are available from the authors. Crystallographic data (excluding structure factors) for the structural analysis have been deposited with the Cambridge Crystallographic Data Centre, CCDC no. 138961. Copies of the data can be obtained free of charge from The Director, CCDC, 12 Union Rd., Cambridge CB2 1EX, UK (fax: + 44-1223336033; e-mail: deposit@ccdc.com.ac.uk or www: http:/ /www.ccdc.cam.ac.uk).

\section{Acknowledgements}

We thank the National Science Council of the Republic of China under the grant NSC87-2113-M-110010 for financial support.

\section{References}

[1] K.S. Suslick, T.J. Reinert, J. Chem. Educ. 62 (1985) 974.

[2] R.D. Jone, D. Summervile, F. Basolo, Chem. Rev. 79 (1979) 139.

[3] T.L. Poulos, Adv. Inorg. Biochem. 7 (1988) 1.

[4] T.L. Poulos, B.C. Finzel, in: M.T.W. Hearn (Ed.), Peptide and Protein Reviews 4, Marcel Dekker, New York, 1984, p. 115.

[5] H.B. Dunford, J.S. Stillman, Coord. Chem. Rev. 19 (1976) 187.

[6] G.R. Schonbaum, B. Chance, in: P.D. Boyer (Ed.), The Enzymes, Academic Press, New York, 1976, p. 295.

[7] W.R. Scheidt, C.A. Reed, Chem. Rev. 81 (1981) 543.

[8] Z.R. Korszun, K. Moffat, J. Mol. Biol. 145 (1981) 815.

[9] (a) M.R. Perutz, J.K.M. Sanders, D.H. Chenery, R.W. Noble, R.R. Penelly, L.W.-M. Fung, C. Ho, I. Giannini, D. Porschke, H. Winkler, Biochem. 17 (1978) 3640. (b) C. Messana, M. Cerdonio, R. Shenken, R.W. Noble, G. Fermi, R.N. Perutz, M.F. Perutz, Biochem. 17 (1978) 3652. (c) P. George, J. Bettlestone, J.S. Griffith, Rev. Mod. Phys. 36 (1964) 441.

[10] M.G.B. Drew, A.H. Othman, P.D.A. McIlroy, S.M. Nelson, J. Chem. Soc. Dalton Trans. (1975) 2507.

[11] (a) D.K. Geiger, V. Chunplang, W.R. Scheidt, Inorg. Chem. 24 (1985) 4736. (b) W.R. Scheidt, Y.J. Lee, D.K. Geiger, K. Tayler, K. Hatano, J. Am. Chem. Soc. 104 (1982) 3367.

[12] T.-Y. Dong, C.C. Schei, M.Y. Hwang, T.Y. Lee, S.K. Yeh, Y.S. Wen, Organometallics 11 (1992) 573.

[13] J.F. Lee, M.D. Lee, P.K. Tseng, Chemistry (Chinese) 45 (1987) 50.

[14] K.M. Adams, P.G. Rasmussen, W.R. Scheidt, K. Hatano, Inorg. Chem. 18 (1979) 1892.

[15] W.R. Scheidt, Y.J. Lee, W. Luangdilok, K.J. Haller, K. Anzai, Hatano, Inorg. Chem. 22 (1983) 1516.

[16] W.R. Scheidt, D.K. Geiger, K.J. Haller, J. Am. Chem. Soc. 104 (1982) 495.

[17] (a) U. Gonser, R.W. Grant, in: I.J. Gruverman (Ed.), Mössbauer Effect Methodology, Plenum Press, New York, 1, 1965, p. 21. (b) C. Maricondi, D.K. Straub, L.M. Epstein, J. Am. Chem. Soc. 94 (1972) 4157.

[18] M. Blume, Phys. Rev. Lett. 18 (1967) 305.

[19] W.R. Scheidt, I.A. Cohen, M.E. Kastner, Biochemistry 18 (1979) 3546.

[20] S.G. Sligar, Biochemistry 15 (1976) 5399. 